\title{
Determination of selected heavy metals in inland fresh water of lower River Niger drainage in North Central Nigeria
}

\author{
Olatunde Stephen Olatunji ${ }^{1 *}$ and Oladele Osibanjo ${ }^{2}$ \\ ${ }^{1}$ Department of Chemistry, Faculty of Applied Sciences, Cape Peninsula University of Technology \\ Bellville, Western Cape, South Africa. \\ ${ }^{2}$ Department of Chemistry, Faculty of Science, University of Ibadan, Ibadan, Oyo State Nigeria.
}

Accepted 23 August, 2012

\begin{abstract}
The concentrations of some ferruginous ore associated heavy metals were determined in freshwater from River Niger. Water samples were collected from both upstream and downstream along the mainstream drainage channel, traversing past the steel production industry Ajaokuta between 2003 and 2005. The water samples were digested according to standard methods and tested for Cadmium (Cd), Manganese (Mn), Chromium (Cr), Nickel (Ni), Cupper (Cu), Zinc ( $\mathrm{Zn}$ ) and Lead (Pb) using Unicam 969 atomic absorption spectrophotometer. The mean concentrations $(\mathrm{mg} / \mathrm{L})$ of heavy metals were: $\mathrm{Mn}, 3.85$ $\pm 0.93 ; \mathrm{Zn}, 2.72 \pm 0.57 ; \mathrm{Cu}, 2.17 \pm 0.73 ; \mathrm{Cr}, 2.08 \pm 1.27 ; \mathrm{Ni}, 0.78 \pm 0.12 ; \mathrm{Cd}, 0.05 \pm 0.02 ; \mathrm{Pb}, 0.03 \pm 0.02$. The concentration of $\mathrm{Mn}, 1.74$ to $8.37 \mathrm{mg} / \mathrm{L} ; \mathrm{Cu}, 0.58$ to $4.50 \mathrm{mg} / \mathrm{L} ; \mathrm{Cd}, 0.02$ to $0.13 \mathrm{mg} / \mathrm{L}$ were variable and inundating. The variations in heavy metal levels between sampling stations were not significant $(P>$ 0.05 ) with relative standard deviation from $2 \%$ for $\mathrm{Cd}$ and $\mathrm{Pb}$ to $12.7 \%$ for $\mathrm{Cr}$. The order of dispersion (2 to $14 \%$ ) showed that the measured metals are nearly homogenously distributed in the water with $\mathrm{Cr}$, $\mathrm{Mn}, \mathrm{Cu}$ and $\mathrm{Zn}$ having the highest concentration variations in the water samples. The concentrations of the evaluated heavy metals were within the guideline levels for freshwaters, and did not appear to have significant negative impact on the water quality.
\end{abstract}

Key words: Heavy metals, freshwater, concentrations, quality, variation, distribution.

\section{INTRODUCTION}

Water quality is fundamental to the health and sustenance of aquatic ecosystems and hydrology. The benefits of renewable freshwater to humans include water for drinking, irrigation, industrial uses, production of fish, and for such in-stream uses as recreation, transportation and waste disposal (Jackson et al., 2001). Water also plays a major role in the cycling of materials and can be a vector if it becomes a source that spread harmful substances and diseases.

The quality and stability of river water depends on such factors as lithology of catchment, climatic conditions,

*Corresponding author. E-mail: snf_olatunji@ymail.com. Tel: +27822912934 . atmospheric and anthropogenic inputs etc (Berner and Berner, 1987; Bricker and Jones, 1995; Markich and Brown, 1998; Bellos et al., 2004). Water can be stressed with heavy metal load sourced from weathered soils/rocks, mining and metallurgical releases and industrial emissions (Boari et al., 1997; Adams, 2001). This may exert unsustainable demand on freshwater by aquatic microflora/microfauna, aquatic wild and humans who depend on such waters, and may be exposed to contamination by heavy metals (Biney et al., 1994; Edorh, 2007) and other contaminants and their deleterious consequences. Although heavy metals do not remain in water for long, water catchments can become a source of concern if the levels of heavy metals in them exceed health guideline concentration criteria (Salomon and Forstner, 1984). 
The protection of water and aquatic ecosystem from adverse effects of pollutants such as heavy metals is central to environmental risk management (Bere and Tundisi, 2011). Evaluation and understanding the sources and impact relationship of the effects of heavy metals in water bodies and biological species is important for effective water management, and the preservation of the aquatic ecosystem. This is because trace amounts of such metals can accumulate in the food chain, eventually causing diseases (Gulson et al., 1996; ATSDR, 1999; Windham, 2000). The assessment of water quality is therefore a vital tool to manage land and water resources within a particular catchment (Petts and Calow, 1996).

The levels of heavy metals in some inland rivers in the hinterland and Niger Delta, especially those which empty their content into coastal waters have been reported (Mombeshora et al., 1981; Ajayi and Osibanjo, 1981; Ndiokwere and Guin, 1983; Wogu and Okaka, 2011). Amoo et al. (2005) and Oyewale and Musa (2006) reported levels of heavy metals in Lakes Kainji and Jebba on the upper reach of River Niger. However, environmental and health data concerning the levels and prevalence of heavy metals in inland water of lower River Niger drain are scarce and scattered. There is need for a rational and systematic assessment of heavy metals in the river system environment in view of the siting of a metallurgical industry along the bank of River Niger at Ajaokuta.

In this study, the concentration of Cadmium (Cd), Lead $(\mathrm{Pb})$, Cupper $(\mathrm{Cu})$, Nickel (Ni), Zinc $(\mathrm{Zn})$, Manganese $(\mathrm{Mn})$ and Chromium $(\mathrm{Cr})$ were determined in water samples collected from River Niger at Ajaokuta, in order to establish their baseline levels.

\section{MATERIALS AND METHODS}

\section{Study area}

River Niger arises from Fouta Djallon highland arriving in Nigeria through Kebbi State and flows through to the Atlantic Ocean. The study location is within the extends of River Niger stretch traversing Ajaokuta area in the lower River Niger regime, which is georeferenced within the Lokoja - Okene area delimited by latitudes $7^{\circ}$ and $8^{\circ} \mathrm{N}$ and longitudes $6^{\circ}$ and $7^{\circ} \mathrm{E}$. Lower River Niger is drained by the Niger-Benue River system, which stretches beyond Lokoja down to the Niger Delta where it empties its content into the Atlantic Ocean. Contribution from watershed tributary streams and rivers to the east and west flowing north-south is significant (Figure 1). However, the hydrologies of discharges from the tributaries are grossly changeable and inundating during rainy season to almost completely dry cut in the course of the dry season (GSN, 1986). Activities on lower River Niger around Ajaokuta include fishing, transportation and domestic uses by communities along the bank of the river. A power station and steel production company seats along the bank of River Niger at Geregu and Ajaokuta, respectively.

\section{Sample collection}

Sampling was carried out along the mainstream drainage channel of River Niger traversing past Ajaokuta Steel Company Complex, located on $\mathrm{N} 07^{\circ} 30,669^{\prime \prime}, \mathrm{E} 006^{\circ} 42,275^{\prime \prime}$ and altitude range 74 to
$120 \mathrm{~m}$ at Ajaokuta, North Central Nigeria as shown in Figure 1. Water samples were randomly collected upstream ( $07^{\circ} 32,745^{\prime \prime}$, E $\left.006^{\circ} 42,712 "\right)$ and downstream (N 07 ${ }^{\circ} 28,678^{\prime \prime}$, E $\left.006^{\circ} 42,492 "\right)$ River Niger off Ajaokuta Steel Company over a period of 24 months, encompassing the dry and wet seasons between December, 2003 and November, 2005.

A total of 80 water samples were collected in nitric acid pretreated $1.5 \mathrm{~L}$ polypropylene bottles for metal detection and in 500 $\mathrm{ml}$ amber coloured bottles for physico-chemical assessment. The bottles were labelled and stored in a cooler for onward transfer to the laboratory.

\section{Sample preparation and the determination of physico-chemical} characteristic

The water samples were processed according to the method prescribed by the American Public Health Association (APHA, 1998). The $\mathrm{pH}$ and electrical conductivity (EC) of the water samples were tested using pre-calibrated $\mathrm{pH}$ and conductivity meter, while the determination of dissolved oxygen (DO), biochemical oxygen demand (BOD), chemical oxygen demand (COD), nitrate $\left(\mathrm{NO}_{3}{ }^{-}\right)$, phosphate $\left(\mathrm{PO}_{4}{ }^{3-}\right)$ and ammonia $\left(\mathrm{NH}_{4}{ }^{+}\right)$were tested using the methods of the APHA (1998).

\section{Determination of heavy metals}

Heavy metals in the water samples were determined as described by APHA (1998). The digested water samples were quantified for the heavy metals $\mathrm{Cd}, \mathrm{Cr}, \mathrm{Mn}, \mathrm{Ni}, \mathrm{Cu}, \mathrm{Zn}$ and $\mathrm{Pb}$ in flame of Unicam 969 atomic absorption spectrometer (FAAS). Procedural blanks were prepared and aspirated along with the analytical samples in order to correct for background absorption. The availability and distribution of heavy metals in River Niger water was evaluated by comparing the statistical mean levels of the metals in the water samples, relative to each other.

\section{Determination of seasonal variability of metals}

Seasonal differences in variability of metal levels was determined by comparing the concentration levels of the heavy metals detected in the water samples during wet season with levels detected during dry season using one way analysis of variance (ANOVA).

\section{Recovery studies}

The test of reliability on heavy metals concentration data were checked against spiked water sample in recovery studies carried out in replicates to validate the digestion method. The recovery and coefficient of variation (CV) of the metals in replicates of the spikes water samples ranged: Cd, 91.42 to $93.35 \%$, CV 3.35 to $4.65 \%$; $\mathrm{Mn}, 89.46$ to $92.84 \%$, CV 4.52 to 6.20 ; Cr, 87.65 to $90.29 \%$, CV 4.25 to $9.41 \%$; Ni, 91.55 to $94.45 \%$, CV 5.28 to $10.24 \% ; \mathrm{Cu}, 92.48$ to $94.07 \%$, CV 6.31 to $10.68 \%$; Zn, 91.36 to $93.94 \%$, CV 7.50 to $14.15 \%$; $\mathrm{Pb}, 92.26$ to $95.15 \%$, CV 3.82 to $5.75 \%$. The error associated with the determination of the concentration of the heavy metals $\mathrm{Cd}, \mathrm{Mn}, \mathrm{Cr}, \mathrm{Ni}, \mathrm{Cu}, \mathrm{Zn}$ and $\mathrm{Pb}$ in River Niger water were considered negligible.

\section{RESULTS}

\section{Physico-chemical characteristics of water samples}

The result of the determination of physico-chemical 


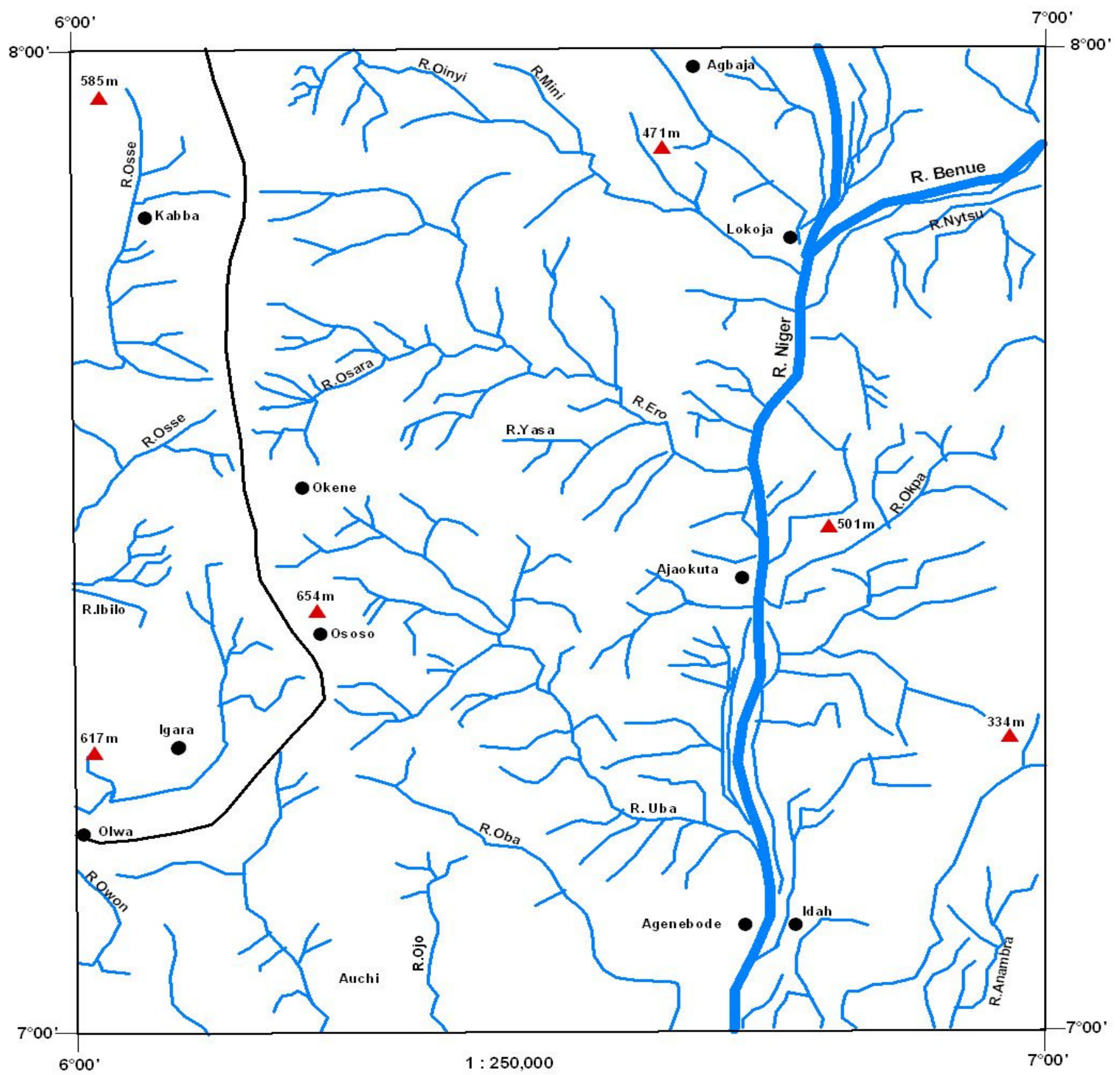

Figure 1. Lower River Niger drainage system with surrogate watershed hydrological pattern on the Lokoja survey area, North Central Nigeria (GSN, 1986).

properties of River Niger water collected at different sampling stations upstream and downstream Ajaokuta Steel Company at Ajaokuta are shown in Table 1.

The $\mathrm{pH}$ of the river water measured at different sampling station ranged from 6.9 to $7.2(7.00 \pm 0.12)$. Water temperature ranged between 24 to $28^{\circ} \mathrm{C}(26.17 \pm$ $1.47^{\circ} \mathrm{C}$ ), with the least temperature measured during wet season. EC of the water ranged from 0.85 to $2.34 \mu \mathrm{S} \mathrm{cm}$ ${ }^{1}\left(1.74 \pm 0.50 \mu \mathrm{S} \mathrm{cm}^{-1}\right)$, and correlates $(\mathrm{Y}=0.58-0.71)$ with total dissolved solid (TDS) levels which ranged from 19.8 to $77.54 \mathrm{mg} / \mathrm{L}(42.95 \pm 20.61 \mathrm{mg} / \mathrm{L})$. DO concentrations ranged from 5.40 to $7.85 \mathrm{mg} / \mathrm{L}(6.67 \pm$
$0.91 \mathrm{mg} / \mathrm{L}$ ), while oxygen demand requirements were BOD, 4.27 to $9.62 \mathrm{mg} / \mathrm{L}(5.58 \pm 2.07 \mathrm{mg} / \mathrm{L})$, and COD, 18.52 to $22.46 \mathrm{mg} / \mathrm{L}(19.56 \pm 1.47 \mathrm{mg} / \mathrm{L})$. Nutrient load levels were $\mathrm{NO}_{3}^{-}, 0.65$ to $1.49 \mathrm{mg} / \mathrm{L}(1.03 \pm 0.30 \mathrm{mg} / \mathrm{L})$, $\mathrm{PO}_{4}{ }^{3-}, 0.41$ to $0.87 \mathrm{mg} / \mathrm{L}(0.63 \pm 0.15 \mathrm{mg} / \mathrm{L})$ and $\mathrm{NH}_{4}{ }^{+}$, 0.15 to $0.42 \mathrm{mg} / \mathrm{L}(0.32 \pm 0.09 \mathrm{mg} / \mathrm{L})$.

\section{Concentration levels, distribution and seasonal variation of heavy metals}

The seasonal concentrations $(\mathrm{mg} / \mathrm{L})$ range of heavy 
Table 1. Physical and chemical characteristics of water from River Niger at Ajaokuta area.

\begin{tabular}{lccccc}
\hline \multirow{2}{*}{ Parameters } & \multirow{2}{*}{ Minimum } & \multirow{2}{*}{ Maximum } & \multirow{2}{*}{ Mean \pm SD } & \multicolumn{2}{c}{ Fresh water quality guidelines } \\
\cline { 6 - 6 } & & & & ANZECC & CCME \\
\hline Electrical conductivity $\left(\mu \mathrm{S} \mathrm{cm}^{-1}\right)$ & 0.90 & 7.20 & $7.00 \pm 0.12$ & - & $6.0-9.0$ \\
Temperature $\left({ }^{\circ} \mathrm{C}\right)$ & 24.38 & 28.07 & $26.17 \pm 1.47$ & $21.5-28.0$ & - \\
Total dissolved solids $(\mathrm{mg} / \mathrm{L})$ & 19.80 & 77.54 & $42.95 \pm 20.61$ & - & - \\
Dissolved oxygen $(\mathrm{mg} / \mathrm{L})$ & 5.40 & 7.85 & $6.67 \pm 0.91$ & $4-8$ & Variable \\
Biochemical oxygen demand $(\mathrm{mg} / \mathrm{L})$ & 4.27 & 9.62 & $5.58 \pm 2.07$ & $3-6$ & - \\
$\mathrm{Chemical} \mathrm{oxygen} \mathrm{demand}(\mathrm{mg} / \mathrm{L})_{\mathrm{PO}_{4}{ }^{-}(\mathrm{mg} / \mathrm{L})}^{18.52}$ & 22.46 & $19.56 \pm 1.47$ & - & - \\
$\mathrm{NO}_{3}{ }^{-}(\mathrm{mg} / \mathrm{L})$ & 0.41 & 0.87 & $0.63 \pm 0.15$ & 0.01 & 0.1 \\
$\mathrm{NH}_{4}{ }^{+}(\mathrm{mg} / \mathrm{L})$ & 0.65 & 1.49 & $1.03 \pm 0.30$ & $0.017-17$ & 13 \\
\hline
\end{tabular}

CCME - Canadian Council of the Ministers of Environment (1999); ANZECC, Australia and New Zealand Environment and Conservation Council (2000): SD, standard deviation.

Table 2. Ranges and mean concentrations (mg/L) of heavy metals in water samples from River Niger at Ajaokuta.

\begin{tabular}{lccccccc}
\hline Sample identity & $\mathbf{C d}(\mathbf{m g} / \mathbf{L})$ & $\mathbf{M n}(\mathbf{m g} / \mathbf{L})$ & $\mathbf{C r}(\mathbf{m g} / \mathbf{L})$ & $\mathbf{N i}(\mathbf{m g} / \mathbf{L})$ & $\mathbf{C u}(\mathbf{m g} / \mathbf{L})$ & $\mathbf{Z n}(\mathbf{m g} / \mathbf{L})$ & $\mathbf{P b}(\mathbf{m g} / \mathbf{L})$ \\
\hline AJK/WS/D/03-04 & & & & & & & \\
Concentration range & $0.05-0.13$ & $2.60-5.58$ & $1.58-3.20$ & $0.75-1.12$ & $1.69-3.57$ & $1.65-3.25$ & $0.02-0.16$ \\
Mean \pm standard deviation & $0.08 \pm 0.02$ & $3.70 \pm 0.90$ & $2.49 \pm 0.58$ & $0.91 \pm 0.12$ & $2.49 \pm 0.65$ & $2.26 \pm 0.49$ & $0.04 \pm 0.03$ \\
& & & & & & & \\
AJK/WS/D/04-05 & & & & & & & \\
Concentration range & $0.03-0.06$ & $3.90-8.37$ & $1.96-4.09$ & $0.59-0.95$ & $2.20-4.50$ & $2.97-4.82$ & $0.01-0.02$ \\
Mean \pm standard deviation & $0.04 \pm 0.01$ & $5.44 \pm 1.29$ & $3.16 \pm 0.65$ & $0.76 \pm 0.13$ & $3.30 \pm 0.79$ & $4.03 \pm 0.66$ & $0.02 \pm 0.01$ \\
& & & & & & & \\
AJK/WS/W/03-04 & & & & & & & \\
Concentration range & $0.04-0.09$ & $1.74-3.57$ & $0.53-2.13$ & $0.48-0.81$ & $0.58-3.03$ & $1.78-3.36$ & $0.02-0.03$ \\
Mean \pm standard deviation & $0.06 \pm 0.02$ & $2.50 \pm 0.61$ & $1.19 \pm 0.52$ & $0.60 \pm 0.11$ & $1.35 \pm 0.84$ & $2.62 \pm 0.53$ & $0.02 \pm 0.01$ \\
& & & & & & & \\
AJK/WS/W/04-05 & & & & & & & \\
Concentration range & $0.02-0.03$ & $2.61-5.36$ & $0.64-2.77$ & $0.68-1.08$ & $0.78-2.55$ & $0.98-3.09$ & $0.01-0.02$ \\
Mean \pm standard deviation & $0.02 \pm 0.01$ & $3.77 \pm 0.92$ & $1.49 \pm 0.71$ & $0.85 \pm 0.12$ & $1.54 \pm 0.65$ & $1.98 \pm 0.58$ & $0.02 \pm 0.01$ \\
\hline
\end{tabular}

Codes: AJK, Ajaokuta; WS, water samples; D, dry season; W, wet seasons; $03-04$, year of sampling cycle 2003 to 2004 ; $04-05$, year of sampling cycle 2004 to 2005.

metals (with mean in parenthesis) (Table 2) during dry season 2003 to 2004 were: $\mathrm{Pb}, 0.02$ to $0.16(0.04 \pm$ $0.03)$; $\mathrm{Cu}, 1.69$ to $3.57(2.49 \pm 0.65) ; \mathrm{Ni}, 0.75$ to 1.12 $(0.91 \pm 0.12) ; \mathrm{Zn}, 1.65$ to 3.25 (2.26 \pm 0.49$) ; \mathrm{Cr}, 1.58$ to 3.20 (2.49 \pm 0.58$) ; \mathrm{Mn}, 2.60$ to 5.58 (3.70 \pm 0.90$)$; $\mathrm{Cd}$, 0.05 to $0.13(0.08 \pm 0.02)$; while during dry season during 2004 to 2005: $\mathrm{Pb}, 0.01$ to 0.02 (0.02 \pm 0.01 ); $\mathrm{Cu}, 2.20$ to 4.50 (3.30 \pm 0.79 ); Ni, 0.59 to 0.95 (0.76 \pm 0.13$) ; \mathrm{Zn}, 2.97$ to $4.82(4.03 \pm 0.66) ; \mathrm{Cr}, 1.96$ to $4.09(3.16 \pm 0.65)$; $\mathrm{Mn}$, 3.90 to 8.37 (5.44 \pm 1.29$)$; $\mathrm{Cd}, 0.03$ to $0.06(0.04 \pm 0.01)$. The concentration levels $(\mathrm{mg} / \mathrm{L})$ of the measured heavy metals during wet season 2003 to 2004 were: $\mathrm{Pb}, 0.02$ to 0.03 (0.02 \pm 0.01 ); $\mathrm{Cu}, 0.58$ to 3.03 (1.35 \pm 0.84 ); Ni, 0.48 to $0.81(0.60 \pm 0.11) ; \mathrm{Zn}, 1.78$ to 3.36 (2.62 \pm 0.53$) ; \mathrm{Cr}$,
0.53 to $2.13(1.19 \pm 0.52) ; \mathrm{Mn}, 1.74$ to $3.57(2.50 \pm 0.61)$ $\mathrm{Cd}, 0.04$ to 0.09 (0.06 \pm 0.02 ) (Table 2); and during wet season 2004 to 2005: $\mathrm{Pb}, 0.01$ to 0.02 (0.02 \pm 0.01$) ; \mathrm{Cu}$, 0.78 to $2.55(1.54 \pm 0.65)$; Ni, 0.68 to $1.08(0.85 \pm 0.12)$; $\mathrm{Zn}, 0.98$ to 3.09 (1.98 \pm 0.58$) ; \mathrm{Cr}, 0.64$ to 2.77 (1.49 \pm 0.71 ); $\mathrm{Mn}, 2.61$ to 5.36 (3.77 \pm 0.92 ); $\mathrm{Cd}, 0.02$ to 0.03 $(0.02 \pm 0.01)$ (Table 2). The overall mean concentration levels $(\mathrm{mg} / \mathrm{L})$ of heavy metals in water collected from the different sampling station in River Niger at Ajaokuta were $\mathrm{Mn}, 3.85 \pm 0.93 ; \mathrm{Zn}, 2.72 \pm 0.57 ; \mathrm{Cu}, 2.17 \pm 0.73 ; \mathrm{Cr}$, $2.08 \pm 1.27 ; \mathrm{Ni}, 0.78 \pm 0.12 ; \mathrm{Cd}, 0.05 \pm 0.02 ; \mathrm{Pb}, 0.03 \pm$ 0.02 . The measured concentrations were generally variable and inundating, except $\mathrm{Cd}$ and $\mathrm{Pb}$ which were fairly nearly consistent throughout. 


\section{DISCUSSION}

The water samples are sufficiently neutral meeting both drinking and freshwater quality requirement 6.5 to 8.5 . DO levels and oxygen demand requirements $(B O D$, were within guideline values for fresh water, except in two water pools $(2 / 80)$ by the riverside with high domestic activities with DO of $<6.00 \mathrm{mg} / \mathrm{L}$, that is, 5.40 and 5.85 $\mathrm{mg} / \mathrm{L}$. The European Union (EU, 2006) freshwater fisheries directive requires that when oxygen concentration falls below $6.00 \mathrm{mg} / \mathrm{L}$, members state should implement provision of article 7(3), which pursues an agenda for water renewal, and aquatic life 'conservation and sustainability. These levels are not a threat to the health of the river water since nutrient load $\mathrm{NO}_{3}{ }^{-}, 0.65$ to $1.49 \mathrm{mg} / \mathrm{L}, \mathrm{PO}_{4}{ }^{3-}, 0.41$ to $0.87 \mathrm{mg} / \mathrm{L}$ and $\mathrm{NH}_{4}^{+}, 0.15$ to $0.42 \mathrm{mg} / \mathrm{L}$ are low. The low nutrient load also explains the low to moderate levels of BOD and $\mathrm{COD}$ requirement. The levels of $\mathrm{DO}, \mathrm{BOD}$ and $\mathrm{COD}$ observed are consistent with the findings of Tripathi et al. (1999), and were within guideline levels. Nutrient levels were also within the Canadian Council of the Ministers of Environment (CCME) guideline levels in freshwater $\left(\mathrm{NO}_{3}{ }^{-}\right.$ , (13 mg/L); $\mathrm{PO}_{4}{ }^{3-},(0.1 \mathrm{mg} / \mathrm{L})$ and $\mathrm{NH}_{4}{ }^{+},(0.025$ and 1.0 $\mathrm{mg} / \mathrm{L}$ for non-ionized ammonia and total ammonium, respectively). Analysis of variance showed that temperature; $\mathrm{pH}, \mathrm{DO}$ and conductivity of water did not show significant variation $(p>0.05)$ between sampling stations. This suggests that the water quality is adequate for supporting aquatic life.

The concentrations of the measured heavy metals in the water samples varied with seasons. The variations in concentration of $\mathrm{Cd}( \pm 0.01$ to \pm 0.02$)$ and $\mathrm{Pb}( \pm 0.01$ to \pm 0.03 ) in the pooled water samples and between sampling stations were not significant $(p>0.05)$, with relative standard deviations of $2 \%, \mathrm{Cd}$ and $\mathrm{Pb}$ to $12.7 \%$ $\mathrm{Cr}$, which indicate uniform distribution as confirmed by the low values (2 to 14\%) of order of dispersion.

River Niger water at Ajaokuta did not contain excessive levels of heavy metals when compared to results from other studies. This finding is consistent with those of Amoo et al. (2005) in freshwater from Lake Kainji on the upper reach of River Niger. Kakulu and Osibanjo (1992) reported higher concentrations of $\mathrm{Cd}, \mathrm{Pb}, \mathrm{Ni}, \mathrm{Cu}$ and $\mathrm{Zn}$ in water collected from Warri River, and higher $\mathrm{Cd}, \mathrm{Pb}$, $\mathrm{Cu}$, and $\mathrm{Zn}$ levels in waters from Calabar River, than recorded in this study. It has been reported that the differences in geography and geologies, as well as activities in various rivers affects the amount of metals present (Berner and Berner, 1987; Bricker and Jones, 1995).

The concentration levels of the measured heavy metals in River Niger water may partly be a function of the prevailing $\mathrm{pH}$ and seasonal variations. According to Ogunfowokan et al. (2005), the availability and toxicity of chemical species of many heavy metals in their aquatic environment is altered depending on the $\mathrm{pH}$ of water body.
The level of Mn was noted to be the most abundant in respect of the other metals determined during the study, followed by $\mathrm{Zn}$. Cd had the least concentration among the metals determined in water samples from River Niger at Ajaokuta. Availability of the metals in River Niger is in the order $\mathrm{Mn}>\mathrm{Zn}>\mathrm{Cu}>\mathrm{Cr}>\mathrm{Ni}>\mathrm{Cd}>\mathrm{Pb}$. The availability sequence observed in this study compares with the report of El-Rayis and Saad (1985) for dissolved metals in surface and subsurface water along the Rosetta branch on River Nile to the eastern Mediterranean. The availability of heavy metals in the upstream drainage area of River Niger is however not significantly $(p>0.05)$ different from the downstream drainage area, though metals abundance trend is the same.

The high concentration of heavy metals in the water samples during the dry seasons under the study period is due to the fact that water levels decrease in rivers, results in increase in concentration of the metals. As a result, the concentrations of the measured metals were higher during dry season than in wet season, exept for $\mathrm{Pb}$ and $\mathrm{Cd}$ which were only slightly altered.

Water quality can be affected when the rate of atmospheric deposition, storm water run offs, domestic or industrial waste water discharges, surpasses the carriage capacity of water (US EPA, 1998). The buffering, dilution and self-purification capacity of large water bodies tends to leave heavy metals levels and those of other hydrophilic substances low (Ajayi and Osibanjo, 1981). It was reported that among water and aquatic quality parameters, salinity, $\mathrm{pH}$ and temperature bears direct stress effect that are naturally and seasonally variable within ecosystem types and for which natural biological communities are adapted to the site-specific conditions (ANZECC, 2000). Water salinity, $\mathrm{pH}$ and temperature have major effect on the bioavailable concentrations of most heavy metals. Thus, the threshold levels for salinity, $\mathrm{pH}$, temperature and priority heavy metals may need to be based on site-specific eco-toxicology and biological effects data.

\section{Conclusion}

The concentrations of heavy metals in River Niger waters at Ajaokuta were found to be low and within guideline levels recommended for freshwater. Results of this study can serve as baseline environmental data benchmark for monitoring build-up of heavy metals in streams and rivers around the metallurgical and steel production environment.

\section{REFERENCES}

Adams SM (2001). Biomarker/bioindicator response profiles of organisms can help differentiate between sources of anthropogenic stressors in aquatic ecosystems. Biomarkers 6:33-44.

Ajayi SO, Osibanjo O (1981). Pollution studies in Nigerian Rivers, II. Water quality of some Nigerian Rivers. Environ. Pollut. (Series B) 2:87-95. 
Amoo IA, Adebayo OT, Lateef AJ (2005). Evaluation of heavy metals in fishes, water and sediments of Lake Kainji, Nigeria. J. Food Agric. Environ. 3(1):209-212.

ANZECC (2000). National Water Quality Management strategy: An introduction to the Australian and New Zealand guidelines for fresh and marine water quality/Australian and New Zealand Environment and Conservation Council and Agriculture and Resource Management Council of Australia and New Zealand. p. cm. (National water quality management strategy; No. 4a).

APHA (1998). Standard methods for the Examination of Water and Wastewater $\left(20^{\text {th }}\right.$ ed). New York: American Public Health, Association (APHA), American Water Works Association (AWWA), and Water Pollution Control Federation (WPCF).

ATSDR (1999). Agency for Toxic Substances and Disease Registry, U. S. Public Health services, 1999. "Toxicology Profile for Mercury" March and April 1999 Media Advisory, New MRLS for toxic substances, MRL: elemental mercury vapour/inhalation/chronic \& MRL: methyl mercury/oral/acute; Retrieved April 21, 2006 from http://atsdr.cdc.gov:8080/97list.html

Bellos D, Sawidis T, Tsekos I (2004). Nutrient chemistry of River Pinios (Thessalia, Greece). Environ. Int. 30:105-115.

Bere T, Tundisi JG (2011). Toxicity and sorption of dissolved cadmium and chromium iii on tropical freshwater phytoperiphyton in laboratory mesocosm experiments. Sci. Total. Environ. 409:4772-4780.

Berner EK, Berner RA (1987). The global water cycle: Geochemistry and Environment: Prentice-Hall, Inc., Englewood Cliffs, NJ, pp. 142155.

Biney C, Amuzu AT, Calamari D, Kaba N, Mbome IL, Naeve $\mathrm{H}$, Ochumba PBO, Osibanjo O, Radegonde V, Saad MAH (1994). Review of heavy metals in the African aquatic environment. Ecotoxicol. Environ. Safety 28:134-159.

Boari G, Mancini IM, Trulli E (1997). Technologies for water treatment. Option mediterraneennes, Ser. A/no31:261-287.

Bricker OP, Jones BF (1995). Main factors affecting the composition of natural waters, In: Salbu B, Steines E (eds). Trace Metals in Natural Waters Chapt. 1:CRC Press, pp. 1-19.

Canadian Council of the Ministers of Environment (CCME) (1999). Protocol for the derivation of Canadian sediment quality guidelines for the protection of aquatic life. Guideline Division, Technical Secretariat of the CCME Task Group on Water Quality Guidelines, Ottawa Canada [reprinted in Canadian Environmental Quality Guidelines, Chapter 6, CCME, 1999, Winnpeg, Canada].

Edorh P (2007). Heavy metal action. TWAS Newsletter. 19(2):42-45.

El-Rayis OA, Saad MAH (1985). Concentration of Cu, Cd, Zn, Fe and $\mathrm{Mn}$ in the Nile river water and its contribution to the Mediterranean. J. Etud. Pollut. 7:45-52.

EU (2006). Directive 2006/44/EC of the European Parliament and of the Council of 6 September 2006 on the quality of fresh waters needing protection or improvement in order to support fish life. Off. J. Eur. Un. L 264/22 En.

GSN (1986). The geology of Lokoja - Auchi Area: Explanation notes on sheet 62. Geol. Survey Report 38:71.
Gulson BL, Korsch KJ, Howarth D (1996). Non-ore body sources are significant contributors to blood lead of some children with low to moderate lead exposure in a major mining community. Sci. Total Environ. 181:223-230.

Jackson RB, Carpenter SR, Dahm CN, McKnight DM, Naiman RJ, Postel SL, Running SW (2001). Water in a Changing World, Issues in ecology, No 9: 2-16 Ecological Society of America, Washington, DC.

Kakulu SE, Osibanjo O (1992). Pollution studies of Nigerian rivers: Trace metal levels of surface waters in the Niger Delta. Int. J. Environ. Stud. 41:287-292.

Markich SJ, Brown PL (1998). Relative importance of natural and anthropogenic influences on the fresh surface water chemistry of the Hawkesbury-Nepean River, south-eastern Australia. Sci. Total Environ. 217:201-230.

Mombeshora C, Ajayi SO, Osibanjo O (1981). Pollution studies on Nigerian rivers: Toxic heavy metal status of surface waters in Ibadan City. Environ. Int. 5:49-53.

Ndiokwere CL, Guinn VP (1983). Determination of some toxic trace metals in Nigerian river and harbour water samples by neutron activation analysis. J. Radioanal. Chem. 79:147-151.

Ogunfowokan AO, Okoh EK, Adenuga AA, Asubiojo OI (2005). An assessment of the impact of point source pollution from a university sewage treatment pond on a receiving stream: A preliminary study. $\mathrm{J}$. Appl. Sci. 5(1):36-43.

Oyewale AO, Musa I (2006). Pollution assessment of the lower basin of lakes Kainji /Jebba, Nigeria: heavy metal status of the waters, sediments and fishes. Environ. Geochem. Health 28(3):273-281.

Petts G, Calow P (eds.) (1996). River Biota: Diversity and Dynamics. Blackwell Science, Oxford. 716-X. p. 257.

Salomon W, Forstner U (1984). Metals in hydrocycle Berlin: Springer.

Tripathi RD, Ali MB, Rai UN, Pal A, Singh SP (1999). Physico-chemical characteristics and pollution level of Lake Nainital (U. P. India): role of macrophytes and phytoplankton in biomonitoring and pyhtoremediation of toxic metal ions. Chemosphere 39(12):21712182.

US EPA (1998). National Water Quality Inventory 1996 Report to Congress, Office of Water (4503F) Washington, DC 20460, United States Environmental Protection Agency, EPA841-F-00-006 June 2000.

Windham B (2000).Cognitive and behavioural effect of toxic metals (over 150 medical study references). Retrieved June 20, 2003, from www.home.earthlink.net/ berniew1/tulbn.hml

Wogu MD, Okaka CE (2011). Pollution studies on Nigerian rivers: heavy metals in surface water of Warri River, Delta State. J. Biodivers. Environ. Sci. 1(3):7-12. 